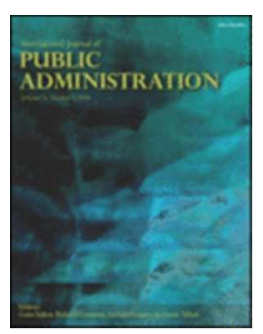

\title{
Social Impact Bonds: Blockbuster Or Flash In A Pan?
}

\begin{tabular}{|r|l|}
\hline Journal: & International Journal of Public Administration \\
\hline Manuscript ID: & Draft \\
\hline Manuscript Type: & Paper \\
\hline Keywords: & $\begin{array}{l}\text { social impact bonds, social impact investment, pre-diffusion study, public } \\
\text { procurement, social service delivery }\end{array}$ \\
\hline
\end{tabular}

\section{SCHOLARONE ${ }^{\text {M }}$}

Manuscripts 
Social Impact Bonds: Blockbuster Or Flash In A Pan? 


\begin{abstract}
Despite the general hype, Social Impact Bonds' (SIB) rate of adoption is still modest. The mismatch between widespread interest and actual adoption raises interesting questions as to whether we are still in the early adoption phase of SIBs and massive diffusion is yet to come, or we are observing a marginal phenomenon. In order to shed some light on this issue, the paper provides a review of the cases in which the SIB model has been already applied, exploring the specific configuration employed, with the purpose to identify regular configuration patterns and their deviation from a prototypical structure.
\end{abstract}

Keywords: social impact bonds, social impact investment, pre-diffusion study, public procurement, social service delivery 
Social Impact Bonds: Blockbuster Or Flash In A Pan?

Over the last few years, the Social Impact Bond (SIB) model has emerged as a new and innovative way for financing social programs, introducing a new type of public-private partnership to provide social (goods and) services (Hangl, 2014; Jackson, 2013; Nicholls \& Tomkinson, 2013; Stoesz, 2014).

The interest in this instrument is certainly motivated by different macro-trends that have characterized the last decade. On the demand-side, the financial crisis of 2008 has led to two contrasting dynamics: the emergence of new and increasingly acute social needs, often coming along with the decrease of families' income and increasing level of unemployment, and the call for policies oriented to cut public spending in order to contain public debt and deficit (Harisalo \& McInerney, 2008; Karanikolos, Mladovsky, Cylus, Thomson, Basu, Stuckler, Mackenbach \& McKee, 2013; Vis, Kersbergen \& Hylands, 2011). This situation determined an urgent need to modify the public approach to deliver or purchase social services, inducing policy makers to look at third sector organizations as well as private sector companies, as viable outsourcers, with a potential of being more efficient and effective than their public sector counterparts (Allen, 2009; Millar, 2012). On the supply-side, the financial market is witnessing the rise of a new breed of investors willing to intentionally pursue social impact alongside the financial return (Bugg-Levine \& Emerson, 2011). New instruments have been designed to target this category of investors, namely "social investment" or "social impact investment", that, broadly speaking, refer to a monetary investment in initiatives whose primary purpose is delivering social services while ensuring a financial return to investors (Kingston \& Bolton, 2004; Loder, Mulgan, Reeder, Aylott \& Shelupanov, 2011; Mulgan, Reeder, Aylott \& Bo’sher, 2010).

In this context, the SIB model, as a form of social impact investing, started to be looked at as a possible response to the problem of funding service delivery through an 
instrument able to foster efficiency, effectiveness and innovation (Fox \& Albertson, 2011). Policy makers in several countries claimed for an increased use of SIBs and highlighted the need of creating an adequate ecosystem to enhance the use of these instruments (G8 Social Impact Investment Taskforce, 2014).

Despite their growing interest towards this new model and the positive reaction of policy makers at the international level, it is worthy to note that SIBs cannot, and do not aim to, substitute traditional methods to finance social projects, and their feasibility and effectiveness can vary from case to case (Fox \& Albertson, 2012; Liebman, 2011; Moynagh, 2010; Mulgan et al., 2010).

Ever since the first SIB Pilot (HMP Peterborough Social Impact Bond) was launched in UK in 2010, twenty-five SIBs have been commissioned in different areas, including U.S., Australia, Canada, Belgium, the Netherlands and Germany (G8 Social Impact Investment Taskforce, 2014; Social Finance, 2014b;) and half of them are currently in operation (OECD, 2015; Social Finance, 2014b). Moreover, many countries, such as Ireland, Israel, Korea, Japan, France, Italy and Scotland are showing interest in this model, and a few international organizations (e.g. U.K. Department for International development; Instiglio; Inter-American Development Bank) are evaluating the use of the SIB paradigm to fund projects in Developing Countries such as India, Columbia, Mozambique, Uganda.

Despite such blistering interest all around the world and the positive reaction of policy makers, SIBs' rate of adoption is still relatively modest and the diffusion curve is far from ramping-up. Around 30 pilot projects or seminal experiences in four years are indeed a small lot, although there is some evidence of progression. This mismatch between widespread interest and actual adoption raises interesting questions as to whether SIBs are the new financial blockbuster or a mere flash in the pan. This urges researchers to understand whether 
we are still in the early adoption phase and massive diffusion is yet to come, or, on the contrary, we are observing a marginal, niche phenomenon.

It is not an ambition of this paper to directly answer this question, but we aim to contribute to the current debate by proposing a possible argument to support a pre-diffusion hypothesis. The SIB instrument has not found its dominant design yet - i.e. a stable set of characteristics related to the specific configuration, in terms of users, financial structure, public accounting arrangements, scope of application - and this represents an obstacle to the breakthrough of this approach in funding social intervention.

In order to shed some light on this issue, we provide a review of the cases in which the SIB model has been already applied, exploring the specific configuration employed, with the purpose to identify regular configuration patterns and their deviation from a prototypical SIB structure, whose features are stated in literature quite clearly. Then, based on this analysis, we conclude with the identification of some key obstacles that, in our opinion, should be solved to allow the actual diffusion of these financial instruments.

The rest of the paper is articulated as follows. We first briefly define what social impact bonds are, discussing pros and cons generally associated to their adoption (Section 2) and we outline the research approach (Section 3). Then, we review the existing SIB experiences at the international level, analyzing the configurations adopted to understand if they adhere to the "SIB prototype" and which dimensions have been arranged differently (Section 4).

Finally, we conclude in Section 5, discussing the implications of this work from a policy and academic perspective.

\section{Social Impact Bonds}

In spite of their name, Social Impact Bonds are not bonds in the conventional sense (Warner, 2013). They can be better defined as hybrid instruments with elements of both equity and debt (Bolton \& Savell, 2010; Liebman, 2011;). In detail, SIBs represent a 
financing mechanism aimed to fund preventive interventions relying on an outcome-based contract. In this model, investors, through a financial intermediary, pay for a certain social service aimed to reach an outcome that is of interest to a government commissioner. If the provided services do produce the agreed results, the government commissioner repays the investors for their initial investment plus a return for the financial risks they took. If not, the investors lose their investment. Hence, SIBs are characterized by three distinguishing features: (1) focus on preventive interventions; (2) adoption of a Payment by Result contract; (3) development of a complex stakeholders' network, including public and private organizations.

In the reference model, the government commissioner enters a contract with a private financing intermediary (i.e. the bond issuing organization), which agrees to provide up front capital to finance the delivery of a preventive social program by service providers with a proven track. The intermediary obtains operating funds by raising capital from one or more non-government, private investors; it uses the funds to contract with the service providers, supporting a specific intervention. An independent assessor is in charge of defining the evaluation methodology and assessing and reporting on the target outcomes. Then, the public sector is required to repay the intermediary only if the intervention is successful, i.e. the social program accomplishes certain pre-defined and agreed social outcomes. In case of success, the intermediary, so, returns principal plus interest to investors. On the contrary, if the outcomes are not reached, investors do not recover their investment (Fox \& Albertson, 2012; Liebman \& Sellman, 2013; Pellini \& Chauvenet, 2011; Warner, 2013).

This articulation is at the basis of some significant advantages of the SIB model compared to traditional methods to procure social services. First, the SIB model does not rely on Government or contractors for covering up-front costs of service provision, because this is up to the financial intermediaries that raise funds from different types of investors. In this 
way, SIBs overcome, at least partially, the problem of constraints to the public funding and free service providers, in particular third sector organizations, from the need of performing fundraising activities (Fox \& Albertson, 2011; Loder et al., 2011; Warner, 2013).

Second, the SIB model redesigns the relationships between partners involved in the commissioning of social services (Nicholls \& Tomkinson, 2013; Palandijan \& Hughes, 2014) and contribute to align the interests of multiple stakeholders with distinct backgrounds and mandates - government commissioners, third sector organizations, private organizations, financial intermediaries, investors (Charlton, Douglas, Flatau \& Gill, 2013; Goodall, 2015; Nicholls \& Tomkinson, 2013; Social Finance, 2013). Thanks to this new network of relationships, SIBs can foster innovation, by leaving service providers free to design new initiatives to achieve the expected social outcome, by exploiting synergies between different actors, by reconfiguring the structure of service delivery, by creating opportunities of crossfertilization between different sectors of the public administration (Jackson, 2013; Social Finance Inc., 2012).

On the other hand, SIB model's opponents have underlined several challenges involved in the adoption of this instrument (Joy \& Shields, 2013; McHugh, Sinclair, Roy, Huckfield \& Donaldson, 2013; Pauly \& Swanson, 2013). First, the fundamental underpinning mechanism of SIB, i.e. the measurement of results, raises some concerns since it could make delivery organizations to focus on those services whose outcomes determine payments (Disley \& Rubin, 2014) because are easier to measure or are more likely to succeed (Fox \& Albertson, 2011). Furthermore, establishing a casual link between the intervention and its outcome is generally complex and stakeholders are incentivized to manipulate outcomes measures (Jackson, 2013; Liebman, 2011). Finally, this scheme could favor larger organizations "at the expense of small, local and distinctive ones" (Dominey, 2012, p. 345), by choosing those projects with a proven track record since they can more likely ensure large 
and certain social returns, in order to limit the private investors' risk (Fox \& Albertson, 2012).

Also on the public agency side, the realization of cashable savings for the public agencies is contingent upon several factors and results may not be clearly ascribable to one single agency's budget (Fox \& Albertson, 2011; Nicholls \& Tomkinson, 2013). Furthermore, the cost of capital of private investors is higher than government's one and the complexity and expensiveness of this partnership may be not counterbalanced by enough benefits, making easier for public administrations to directly finance social programs (Mulgan et al., 2010).

Hence, in the end, given the above-mentioned requirements of SIB model, few programs and populations could really have the necessary conditions for the SIB model to be applied (Jackson, 2013; Mulgan et al., 2010).

\section{Design And Methodology}

The purpose of this paper is to investigate regular configuration patterns in SIB design and to understand if and how they diverge from prototypical SIB structure defined in literature. This exploration poses the basis for discussing the hypothesis put forth in the introduction, i.e. the absence of a SIB dominant design is inhibiting the instrument's breakthrough. Hence, moving from the presentation of the pros and cons of the application of the SIB model, carried out in the previous paragraph, we now introduce the research approach, discussing how the review of the SIB experiences was carried out and how empirical material was analyzed.

The methodology is articulated into three steps: (1) mapping of the SIB experiences implemented so far; (2) identification of the SIB experiences that are compliant with some first-tier characteristics, emerging from the literature as a "must have" in order to achieve the benefits generally associated with SIB model; (3) analysis of the SIB configurations, based 
on a set of pre-defined dimensions in order to identify the cases that have adopted a configuration deviating from the SIB prototype and single out other possible recurring configurations.

\section{Mapping Of SIB Experiences}

The first step consists in the identification of the SIBs experiences implemented so far. To this aim, the mapping performed by Social Finance (Social Finance, 2014b) was used as a starting point since this body is generally considered a reference organization at the international level. This initial mapping was completed through the analysis of other influential sources, including academic and practitioners literature such as consulting companies' reports, technical working group and non governmental organization active in this field ${ }^{1}$ and press releases.

This process allowed identifying six further cases for which it was possible to collect adequate information concerning the SIB structure ${ }^{2}$. In details, we added two cases from Israel; three more cases from U.S.; one more case from the UK. The output of this process is reported in Table 1 that provides an exhaustive representation of SIB projects already in place or in the process of being implemented worldwide till February 2015. It includes $31^{3}$ SIBs that have been initiated between 2010 and 2015 in eight countries (UK, U.S., Australia, Canada, Belgium, Netherlands, Israel and Germany) and that are currently in different stage of development.

Please Insert Table 1 here

\section{Screening Of SIB Experiences}


The second step consists in the identification of the SIB experiences that are compliant with the first-tier characteristics a SIB is supposed to have in order to achieve the main benefits generally appointed to this instrument. As highlighted in Section 2, a SIB is supposed to fund an innovative and preventive social program (Social Finance, 2014a), through an outcome-based contract. It involves different actors that are characterized by distinct roles: a commissioner, one or more delivery agencies and one or more investors, which are different from both the commissioning and the delivery agency (Center for Social Impact Bonds, 2013). Since private investors provide the upfront working capital, which is paid back only if target results are actually met, they bear the whole program risk (Dagher, 2013; Lehner \& Nicholls, 2014; Loder et al., 2011; Nicholls and Tomkinson, 2013; Ragin \& Palandjian, 2013; Warner, 2013).

Please Insert Table 2 here

In many cases, not all these characteristics are recognizable in the analyzed experiences. In particular, two features - the presence of an innovative and preventive program and the transfer of risk to private investors - have not been implemented in several cases. Most of these SIBs are used to provide more funds to existing intervention, which do not necessarily require the collaboration and integration between different operators to be implemented. Moreover, the financial structure of several SIBs includes mechanisms to lower investors' risk by protecting their principal through philanthropic or public money or engaging other actors, such as the service providers, in sharing this risk. This suggests that the SIB scheme involves an imbalance between the level of risk and the rate of return, which may discourage traditional investors, not driven by a social purpose, to invest. 
Among the analyzed SIBs, there are also two cases that appear to be really far from the original SIB idea (Newpin Social Benefit Bond and Bristol Together). In these cases, the SIB structure is completely altered since three out of five dimensions have been avoided. Hence, they have been excluded from the subsequent analysis.

\section{Analysis Of SIB Configurations}

The last step consists in the analysis of the SIB configurations in order to verify (1) if these SIB experiences have been designed coherently with the prototypical SIB structure that is presented in literature and (2) which design dimensions have been characterized by higher variance. To this aim, we refer to eight aspects that allow characterizing a SIB (again identified on the basis of a review of the academic and practitioners literature):

1. Coverage of a social issue: this dimension refers to if and how a social issue is already addressed by existing services provided by public sector organizations. In particular, a SIB can address an area that is (1) uncovered by the public offerings, due to a lack of resources, (2) uncovered by public offerings, since it is not a statutory service or (3) covered by the public offerings, with poor outcomes or poor outreach.

2. Innovation of the program: this dimension describes the features of the social intervention financed by the SIB. A SIB can fund (1) a program that is totally new; (2) the implementation of a program, whose underpinning principles (e.g. a specific therapy) have already been tested with a positive outcome, but it has not been implemented yet; (3) the expansion of an existing program that has already been implemented in prior cases.

3. Target area: this dimension specifies the geographical area targeted by a SIB. In details, an intervention can be implemented at (1) local (city) level, (2) regional (county, State) level, (3) country level (nationwide). 
4. Nature of the promoter: this dimension illustrates whether the SIB has been promoted by (1) public administrations at different government levels (State/National, Regional, Local...) or (2) private organizations.

5. Involvement of the commissioner: this dimension addresses the role of the commissioner towards service providers and its level of control over the organizations involved in the SIB. This can result in a (1) high or (2) low level of involvement.

6. Flexibility of the delivery structure: this dimension deals with the relationship between service providers and between service provider/s and the intermediary. The interactions among actors can lead to (1) flexible and collaborative arrangements, (2) well-established boundaries and collaborative relationship (3) well-established boundaries and limited possibilities to activate collaborative processes among public and private operators.

7. Risk allocation: this dimension refers to the allocation of risk between the organizations involved in a SIB. In this connection, risk can be (1) bore by private investors or (2) can be distributed among different actors (public and private) through capital protection measures and risk sharing arrangements.

8. Distribution of potential savings: this dimension addresses the relationship between the potential savings generated by the intervention and the outcome payments made by the commissioner. It is important to understand if the cost savings generated by a SIB can be directly accrued to (1) one single Department, contributing to reduce a specific cost item, (2) more than one Departments, contributing to reduce a set of well defined cost items, (3) the overall community, but without a specific link to a precise cost item. 


\section{Results}

In this section, we outline the results of the analysis, in terms of adherence of the SIB experiences to the SIB prototype and identification of the design dimensions that present higher variability (Annex 1).

In this way, three groups with a different level of adherence to the reference model emerged. As follows, we refer to these three groups as: (1) fully compliant SIBs, (2) partially compliant SIBs and (3) marginally compliant SIBs (Table 3). Then, for each group, we have identified the design dimensions against which the analysed SIBs show larger differences from the prototype.

Please Insert Table 3 here

\section{Fully Compliant SIBs}

Only four SIBs, out of twenty, adopted a configuration that is fully coherent with the SIB prototype. Obviously, the HMP Peterborough SIB belongs to this category, since it can be considered the reference model. Then, this group includes SIBs, which address a new program, with an ad hoc social intervention, which has its main strength in ensuring flexibility in designing the program and a high level of customization on the user's need. The HMP Peterborough SIB, for instance, aims to build an individual action plan designed on each prisoner's needs.

To this purpose, the delivery structure is configured as a network of different service providers, which are willing to collaborate and combine the distinct core activities in order to create an innovative intervention. For instance, It's all about me SIB is carried out by a network of Voluntary Adoption Agencies, using a spot purchase logic that allow great flexibility to Local Authorities in buying the service depending on need. 
Within this network, the intermediary plays a leading role in overseeing project implementation, arranging project funding, distributing funds and managing repayment to funders. Again, this is extremely evident in the HMP Peterborough SIB, where several actors are integrated under a unique "umbrella" program, named One Service, which engages different local service providers and a local manager. The latter is in charge of avoiding the rise of governance issues and assessing whether provided services meet the needs of the cohort members (Disley, Rubin, Scraggs, Burrowes \& Culley, 2011). This arrangement has been shaped to allow each provider to use its core competencies and activities to handle a precise step in the rehabilitation process. The high level of flexibility and customization seems to be a prominent feature also in the DWP Innovation Fund SIB, which has succeeded in engaging several service providers and employing an ad hoc model for each one. In this way, the SIB has been able to exploit several innovative social investment models (Center for Social Impact Bonds, 2013): within the same project, the commissioner has experimented three different ways of engaging with the service provider.

This possibility of changing the structure of the intervention easily is allowed also by the low level of control of commissioner, over the intermediary and providers, which distinguishes these SIBs. For example, the DWP Innovation Fund SIB relies on an open competition based on a list of payable outcomes published by the Departement of Work and Pensions, but the bidders can "pick and mix from this list" and they can propose the payments associated to each proxy outcome (Center for Social Impact Bonds, 2013). While, in the HMP Peterborough SIB, the public commissioner has not even chosen the service providers and it has no direct relationship with any of them (Disley \& Rubin, 2014). However, in all three SIBs, the role of the intermediary is crucial. 
In the SIBs included in this group the scope of the intervention is typically nationwide, as in the DWP Innovation Fund SIB and It's all about me SIB, which ensures a potential to transform the rules of public and private engagement at the highest level.

Finally, this dominant configuration does not arrange any measure to lower the risk of private investors, which provide the total amount needed to fund the intervention and may lose their principal if the target outcomes are not met.

To sum up, this specific configuration enables a greater flexibility of the intervention in terms of changing the program structure to answer to the user's need and leaving the provider free to choose the right means to reach the agreed outcome. Thus, it seems able to realize the SIB potential benefit of shifting the paradigm of procurement from processes to outcomes (Dermine, 2014; Fox \& Albertson, 2011;) and foster efficiency in the use taxpayers' money, which can be used to finance just "what works". In addition, it allows exploring new forms of engagement with and between the service providers, fulfilling the need of selecting effective service providers and of deploying money just in successful programs.

\section{Partially Compliant SIBs}

The second group includes those SIBs that are only partially coherent with the SIB prototype.

The SIBs that have been included in this group are all implemented at local or regional level, which means that their transformative power, toward the public-private engagement paradigm, remains limited. Consequently, the commissioner, which is the local authority, generally plays a prominent role: it is highly involved in commissioning, designing and implementing the SIB and it sometimes has a direct relationship with the service provider. For instance, in the Street Impact SIB, the Great London Authority has entered into a contract directly with one of the service providers; the SIB is presented as a component of a 
broader public strategy (Essex City Council SIB); or the local authority commits dedicated staff and officers of the organization to the project (Manchester City Council SIB).

SIBs included in this group exhibit a first gap in terms of innovativeness of the program. Indeed, they were typically used to fund the expansions of existing programs or the implementation of a program already proven successful rather than providing the fund enabled the test something new. Moreover, just few experiences have been able to structure the SIB in order to improve the existing program by including relevant opportunities of collaboration between different non-profit providers or between these and the staff of the public agencies. Therefore, the major part of SIBs in this group shows an arrangement where a new program has been created by a not for profit organization to cover an area not fulfilled by public offerings, but its transformative potential, in terms of testing something new and fostering collaboration between public and private actors, is very scant. For instance, this configuration characterized the two SIBs, which intervene in the health sector by providing new preventive program to warn the appearance of asthma and diabetes. The inconsistency from the prototype model in these two dimensions, the innovativeness and flexibility of the program, inhibits the benefit of reforming the mainstream logic of public-private partnership in providing social services ensured by the prototype.

A further relevant difference that is common to all the SIBs included in this group compared to the prototype is the inclusion of risk mitigation arrangements for private investors. In particular, two mechanisms have been employed in the SIB experiences, alternatively or complementarily: (1) part or the whole investment has been guaranteed by a third private entity (i.e. a foundation) or by the public commissioner itself; (2) the service provider shares part of the risk by supplying part of the upfront capital or by binding part of its fees to the achievement of results. For instance, in the Rikers Island SIB, the nonprofit, research organization MDRC, who acts as intermediary, received a grant from Bloomberg 
Foundation in order to guarantee the debt; in the New York State Social Impact Partnership SIB, a guarantee facility was provided by the Rockefeller Foundation to cover $10 \%$ of the private investment; in the Street Impact SIB, the service provider shares the risk with the investors by supplying a part of the capital and they will get financial return in case of project's success. In the Juvat SIB: just non-profit financiers invested in the project and they assumed the entire risk. Though this feature was presented by the SIB's promoters as a plus that sets this case apart from the debate over the role of private investors in implementing SIBs, it frustrates the benefit potentially associated with the transfer of the implementation risk to private investors. Hence, it can suggests that the mainstream market is still not ready for these new types of financial instruments.

\section{Marginally Compliant SIBs}

The last group includes those SIBs that are quite far from the ideal SIB prototype. These SIBs generally fund the expansion of an existing program usually carried out by one single service provider; despite being based on a payment-by-results logic, the actors agree to support that particular intervention rather than the achievement of specific outcomes. Therefore, the leeway for service providers to organize the work as they prefer is very limited. Illustrative in this sense are all the SIBs implemented in United States. These SIBs are characterized by the presence of one service provider in charge of expanding the outreach of one of its programs, without the aim of collaborating and integrating competencies of different actors.

Furthermore, these SIBs are commissioned at local level with a high involvement of the promoter. In both Massachusetts SIBs, the Commonwealth has played a strong role in the commissioning and designing phase of SIB by advocating new solutions from third sector organizations through an open request (Juvenile Justice Pay for Success Initiative) and it has appointed, through a competitive process, both the intermediary and the social program to 
implement. Utah School Readiness Initiative SIB provides the funds to expand the outreach of a program that has so far operated in a public district school, just on a small scale. Whereas, in the Benevolent Society Social Benefit Bond, the two commercial banks, that are partners of the service provider, have practically arranged and issued the SIB.

Finally, all the SIBs included in this group are characterized by the presence of mechanisms aimed to lower the risk of private investors. For instance, the Benevolent Society Social Benefit Bond is structured like an actual bond, with traditional capital protection measures. In the Juvenile Justice Pay for Success Initiative SIB, the intermediaries and the service provider share risk by deferring a portion of their own fees, which are also dependent on the outcome. Buzinezzclub SIB involves a provider, which is structured as an enterprise that generates a yield if the program is successful.

\section{Conclusions}

The diffusion of SIBs has been relatively slow, especially when compared to the hype surrounding these instruments all around the world. This low penetration can be explained in two alternative ways, either by arguing that SIBs are still lounging in the early stages of their diffusion curve or by stating that they are structurally a small-scale phenomenon, the limits of which are defined by some hurdles and constraints that generate concerns among public administrators.

The empirical data collected in this paper are certainly not enough to answer this complex question, but they can provide some evidence to support the idea that the SIB diffusion is slowed down by the delayed definition of a dominant design, intended as a stable set of characteristics related to users, financial structure, public accounting arrangements, scope of application.

The review of SIB experiences, in fact, has pointed out different levels of coherence with the reference model, with the majority of SIBs being only partially or marginally 
compliant with the SIB prototype. Furthermore, also within each analyzed group, relevant differences have emerged in relationship to different design dimensions and only SIBs belonging to the marginally compliance group are actually converging towards a common structure.

As in any study dealing with pre-diffusion phenomena, the number of cases is still too little to draw sound empirical conclusions; nevertheless they allow pinpointing some recurring hurdles. First, SIB experiences rarely finance a new program whose innovation stands in creating an integrated supply chain of service providers with different core competencies or in opening collaborative opportunities between public and private professionals, besides the intervention strategy. Second, the shift of focus on the achievement of outcomes, rather than on the means to attain these, is hindered when SIB's contract involves a specific and welldefined intervention. The benefit for service providers and public sector of dealing with a flexible intervention that at the same time ensures a greater level of efficiency and effectiveness disappears. Third, the number of cases where private investors do not borne the entire risk of the intervention are many; in so far as, nonprofit sector organizations, such as foundations, or the State will intervene to back the private capital, the hope to engage mainstream investors in the social impact investment market remains remote.

This situation appears particularly critical since SIBs implemented in practice are diverging from the SIB prototype especially by avoiding those elements that would allow the instrument to go beyond the traditional logic of public procurement for reengineering, and thus increasing the efficiency, of the public expenditure supply chain.

A possible explanation for this phenomenon is the presence of some relevant challenges in the ecosystems where SIB model should be implemented, which prevent the enactment of the prototypical SIB structure. These challenges can be related to four key 
issues: the legislative framework; the prevailing approach to public procurement; the public accounting framework; and the measurement infrastructure.

First, the legislative framework is still quite confused and constraining (European Commission, 2014). In many countries organizations with a social aim have to surf among different legal status and, at the same time, the current legal forms are not able to include those organizations that operates in sectors which address social problems without configuring themselves as a "not for profit" entity. These constraints reduce the number and type of organizations that can be involved in a SIB experience, for building new supply chains and foster innovation. Therefore, it would be crucial to promote more inclusive laws able to cover and regulate the whole universe of potential social service providers, going beyond the "non profit" or "for profit" legal status. This would result, first, in a broader numbers of organizations which could be engaged in a SIB and, second, in greater probability to intercept those organizations eager to adopt innovative intervention model.

The second obstacle refers to the prevailing model of public procurement. In many countries, current rules of public social procurement tend to favor the criterion of "the lowest price" rather than the quality of the intervention. Important aspects such as innovativeness, userorientation, relationship with local community, which typically characterized organizations with an explicit social purpose, are not appraised in the competition for funding. Obviously, this circumstance reduces the possibility of involving actors aiming to innovate the social service provision or to enlarge the range of services provided. Therefore, this mechanism should be renovated in order to enhance the use of new instruments, able to reward a fair balance between the effective and efficient achievement of outcomes.

Third, in many countries, the accounting framework that is used in the public sector prevents the SIB implementation. For instance, the Italian public accounting system does not allow the public administration to commit itself in the long term for an expense that is undefined both 
in occurrence and amount, that is exactly the situation of that characterizes SIB outcomes payments. In order to overcome this constraint, it would be helpful to identify specific cost centers, which are part of the public endowment, but are quite independent in terms of governance and accounting rules. An example, regarding the criminal justice field, is the Italian "Cassa delle ammende", which collects all the procedural penalties and it is managed by the head of Prison Administration Department.

Lastly, SIB model is based on a fundamental precondition, i.e. the ability the measure the outcomes of the intervention. Therefore, the underdevelopment of social impact measurement culture and practice implies that SIB developers cannot count on shared and established methodologies and metrics. This gap makes the development of SIBs a harder work since suitable metrics and indicators should be created from scratch, promoters and investors cannot use past track record about service providers to drive their choices, services providers cannot objectively prove their effectiveness and efficiency (McHugh et al., 2013).

In order to overcome these barriers, SIB developers have been forced to introduce significant modifications in the original SIB structure, losing the opportunity to establish a dominant design to which SIB supporters can advocate. At the end of the day, the lack of a benchmark model is slowing down or preventing SIBs diffusion: the current entropy in the design assumed by SIB experiences hinders the creation of economies of network and learning curves among policy makers and diverts the efforts that could be deployed towards the aforementioned specific issues, which solved may let social impact bonds enter a paradigmatic phase and to become a consolidated practice for procurement of social services. From this perspective, the paper aims to highlight the importance of policy makers carefully considering the factors that are deemed to slow down or prevent the diffusion of SIBs and deploying relevant energies to address them, for example, in term of funds to support the capacity building activities of public administration and the launch of pilots project through 
with testing a shared design. Indeed, the convergence towards a dominant design may be achieved just with an effective engagement of policy makers, at national and supranational level.

Finally we conclude, discussing the paths for future research. As mentioned above, given the infancy phase of SIB market in terms of number of experiences and availability of reliable data, this study is explorative in nature and aims to pave the path for future larger scale research when, and if, more data will be available. In the meantime, further research could explore the diffusion of SIBs over time and to verify if the prototypical SIB structure will be refined thanks to a "learning by doing" effect. In this context, it would also be interesting to explore more in depth the emerging country-specific influences by doing a cross-country analysis in order to understand how much the peculiarities of a country in terms of legal, economic, political and cultural background can affect the SIB design. 
References

Allen, P. (2009). Restructuring the NHS again: supply side reform in recent English health care policy. Financial accountability \& management, 25(4), 373-389. doi: 10.1111/j.1468-0408.2009.00483.x

Bolton, E., \& Savell, L. (2010). Towards a new social economy. Blended value creation through Social Impact Bonds. London, UK: Social Finance Ltd.

Bugg-Levine, A., \& Emerson, J. (2011). Impact Investing: Transforming How We Make Money While Making a Difference. San Francisco, CA: Jossey-Bass.

Center for Social Impact Bonds. (2013). Case studies - existing SIBs. London, UK: UK Cabinet Office. Retrieved from http://data.gov.uk/sib_knowledge_box/case-studiesexisting-sibs.

Charlton, K., Douglas, E., Flatau, P., \& Gill, I. (2013). Understanding Social Impact Partnership. Perth, AU: UWA, Ecotrust Australia.

Dagher, P. G. (2013). Social Impact Bonds and the Private Benefit Doctrine: Will Participation Jeopardize a Nonprofit's Tax-Exempt Status? Fordham Law Review, 81 (6), 3479-3519.

Dermine, T. (2014). Establishing Social Impact Bonds in Continental Europe (Mossavar-Rahmani Center for Business and Government Associate Working Paper Series, No. 26). Boston: Harvard Kennedy School.

Disley, E., \& Rubin, J. (2014). Phase 2 report from the payment by results Social Impact Bond pilot at HMP Peterborough (UK Ministry of Justice Analytical Series). London, UK: RAND Europe.

Disley, E., Rubin, J., Scraggs, E., Burrowes, N., \& Culley, D. (2011). Lessons learned from the planning and early implementation of the Social Impact Bond at HMP Peterborough (RAND Europe, Research Series 5/11). London, UK: RAND Europe.

Dominey, J. (2012). A mixed market probation services: Can lessons from the recent past help shape the near future?. Probation Journal Health Policy and Planning, 24 (3), 160166. doi: $10.1177 / 0264550512458474$

European Commission. (2014). A map of social enterprises and their ecosystems in Europe. Retrieved from http://ec.europa.eu/social/main.jsp?langId=en\&catId=89\&newsId=2149\&furtherNews=yes \& preview $=$ cHJldkVtcGxQb3J0YWwhMjAxMjAyMTVwcmV2aWV3

Fox, C., \& Albertson, K. (2011). Payment by results and social impact bonds in the criminal justice sector: New challenges for the concept of evidence-based policy? Criminology and Criminal Justice, 11(5), 395-413. doi: 10.1177/1748895811415580 
Fox, C., \& Albertson, K. (2012). Is payment by results the most efficient way to address the challenges faced by the criminal justice sector? Probation Journal, 59 (4), 355373. doi: $10.1177 / 0264550512458473$

G8 Social Impact Investment Taskforce. (2014). IMPACT INVESTMENT: The invisible heart of markets. Retrieved from www.socialimpactinvestment.org

Goodall, E. (2015). Choosing Social Impact Bonds. A practitioner's Guide. London, UK: Bridges Ventures LLP and Bank of America Merrill Lynch.

Hangl, C. (2014). A literature review about the landscape of social finance. Journal of Finance and Risk Perspectives, 3(4), 64 - 98.

Harisalo, R. \& McInerney, J. (2008). Welfare State: From Dream to Reality. International Journal of Public Administration, 31(10-11), 1303-1326. doi: 10.1080/01900690801973501

Jackson, E. T. (2013). Evaluating social impact bonds: questions, challenges, innovations, and possibilities in measuring outcomes in impact investing. Community Development, 44(5), 608-616. doi:10.1080/15575330.2013.854258

Joy, M., \& Shields, J. (2013). Social Impact Bonds: The Next Phase of Third Sector Marketization? Canadian Journal of Nonprofit and Social Economy Research, 4(2), 39-55.

Karanikolos, M., Mladovsky, P., Cylus, J., Thomson, S., Basu, S., Stuckler, D., Mackenbach, J.P., \& McKee, M. (2013). Financial crisis, austerity, and health in Europe. The Lancet, 381(9874), 1323-1331. doi: http://dx.doi.org/10.1016/S0140-6736(13)60102-6

Kingston, J., \& Bolton, M. (2004). New Approaches to Funding Not-for-profit Organizations. International Journal of Nonprofit and Voluntary Sector Marketing, 9(2), 112121. doi: $10.1002 /$ nvsm. 238

Lehner, O., M., \& Nicholls, A. (2014). Social finance and crowdfunding for social enterprises: a public-private case study providing legitimacy and leverage. Venture Capital: An International Journal of Entrepreneurial Finance, 16(3), 271-286. doi: 10.1080/13691066.2014.925305

Liebman, J. B. (2011). Social Impact Bonds: A promising new financing model to accelerate social innovation and improve government performance. Center for American Progress. Retrieved from https://cdn.americanprogress.org/wpcontent/uploads/issues/2011/02/pdf/social_impact_bonds.pdf

Liebman, J., \& Sellman, A., (2013). Social Impact Bonds. A guide for State and Local Governments. Harvard Kennedy School \& Social Impact Bond Technical Assistance Lab. Retrieved from http://payforsuccess.org/sites/default/files/social-impact-bonds-a-guide-forstate-and-local-governments1.pdf

Loder, J., Mulgan, G., Reeder, N., Aylott, M., \& Shelupanov, A. (2011). Financing social value: implementing Social Impact Bonds. London, UK: The Young Foundation. 
McHugh, N., Sinclair, S., Roy, M., Huckfield, L., \& Donaldson, C., (2013). Social impact bonds: a wolf in sheep's clothing? Journal of Poverty and Social Justice, 21(3), $247-$ 57. doi: http://dx.doi.org/10.1332/204674313X13812372137921

Millar, R. (2012). Social Enterprise in Health Organisation and Management: Hybridity or Homogeneity?. Journal of Health Organization and Management, 26(2), 143148. doi: http://dx.doi.org/10.1108/14777261211230817

Moynagh, M. (2010). Investing for public good. Creating social value through social impact bonds. Norfolk, UK: The Tomorrow Project.

Mulgan, G., Reeder, N., Aylott, M., \& Bo'sher, L. (2010). Social Impact Investment: the Challenge and Opportunity of Social Impact Bonds. London, UK: The Young Foundation. Retrieved from http://youngfoundation.org/wp-content/uploads/2012/10/SocialImpact-Investment-The-opportunity-and-challenge-of-Social-Impact-Bonds-March-2011.pdf

Nicholls, A., \& Tomkinson, E. (2013). The Peterborough Pilot Social Impact Bond. Oxford, UK: Saïd Business School, Oxford University.

Organisation for Economic Co-operation and Development (OECD). (2015). Social Impact Investment: Building The Evidence Base. Retrieved from http://www.oecd.org/sti/ind/social-impact-investment.htm.

Palandijan, T., \& Hughes, J. (2014). A strong Field Framework for SIBs. Stanford Social Innovation Review. Retrieved from http://www.ssireview.org/blog/entry/a_strong_field_framework_for_sibs.

Pauly, M. V., \& Swanson, A. T. (2013). Social Impact Bonds in Nonprofit Health Care: New Product or New Package? (NBER Working Paper No. w18991). Cambridge, MA: National Bureau of Economic Research.

Pellini, P., \& Chauvenet, C. (2011). Rethinking the Public-Private Partnership. Why a New Approach in the Welfare-related Infrastructures Market is Needed: The Role of Social Bonds (Paper presented at V COLLOQUIO SCIENTIFICO ANNUALE SULL'IMPRESA SOCIALE). Milano, IT: Euricse, Università Commerciale Luigi Bocconi.

Ragin, L. Jr., \& Palandjian, T. (2013). Social Impact Bonds: Using Impact Investment to Expand Effective Social Programs. Community Development Investment Review, 9(1), 6367.

Social Finance Inc. (2012). A New Tool for Scaling Impact: How Social Impact Bonds can Mobilize Private Capital to Advance Social Good. Boston, MA: Author. Retrieved from http://www.socialfinanceus.org/sites/socialfinanceus.org/files/small.SocialFinanceWPSingleF INAL.pdf

Social Finance Ltd. (2013). A Technical Guide to Developing Social Impact Bonds. London, UK: Author. Retrieved from http://www.socialfinanceus.org/sites/socialfinanceus.org/files/sf_svc_guide.pdf 
Social Finance Ltd. (2014a). Fact Sheet: Introduction to Social Impact Bonds. London, UK: Author. Retrieved from http://www.socialfinance.org.uk/services/socialimpact-bonds/

Social Finance Ltd. (2014b). The Global Social Impact Bond Market. London, UK: Author. Retrieved from http://www.socialfinance.org.uk/services/social-impact-bonds/

Stoesz, D. (2014). Evidence-Based Policy: Reorganizing Social Services Through Accountable Care Organizations and Social Impact Bonds. Research on Social Work Practice, 24(2), 181-185. doi: 10.1177/1049731513500827

Vis, B., Kersbergen, K., \& Hylands, T. (2011). To What Extent Did the Financial Crisis Intensify the Pressure to Reform the Welfare State?. Social Policy \& Administration, 45(4), 338-353. doi: 10.1111/j.1467-9515.2011.00778.x

Warner, M. E. (2013). Private finance for public goods: social impact bonds. Journal of Economic Policy Reform, 16(4), 303-319. doi:10.1080/17487870.2013.835727 
Footnotes

${ }^{1}$ Instiglio, Social Ventures Australia, McKinsey, Payforsuccess.org, Social Impact Bond Technical Assistance Lab, Emma Tomkinson, Social Impact Investment Taskforce.

${ }^{2}$ For this reason, we excluded from the analysis the SIB launched in Portugal (February 2015) and the seven SIBs launched (mid-March 2015) by UK Cabinet Office to help disadvantaged young people, children in care and those with long term health conditions and mental illness.

${ }^{3}$ However, in the analysis, we decide to consider the DWP Innovation Fund for Young People as one case even if it consists of 10 SIBs. 
Table 1

Analyzed SIB experiences

\begin{tabular}{|c|c|c|c|c|c|c|}
\hline \# & SIB NAME & SECTOR & COUNTRY & YEAR & DURATION & $\begin{array}{l}\text { INVESTOR } \\
\text { TOTAL }^{\mathrm{a}}\end{array}$ \\
\hline 1 & HMP Peterborough & Criminal justice & $\overline{\mathrm{UK}}$ & 2010 & 8 years & $\$ 7,6$ \\
\hline 2 & Rikers Island & Criminal justice & U.S. & 2012 & 4 years & $\$ 9,6$ \\
\hline 3 & $\begin{array}{l}\text { Juvenile Justice Pay for } \\
\text { Success Initiative }\end{array}$ & Criminal justice & U.S. & 2014 & 7 years & $\$ 21,3$ \\
\hline 4 & Street Impact & Rough sleeping & UK & 2012 & 3 years & $\$ 7,6$ \\
\hline 5 & $\begin{array}{l}\text { Chronic Homeless - Social } \\
\text { Innovation Financing MA }\end{array}$ & Rough sleeping & U.S. & 2014 & 6 years & $\$ 3,5$ \\
\hline 6 & $\begin{array}{l}\text { Resilient Families Service } \\
\text { SBB }\end{array}$ & $\begin{array}{l}\text { Children and } \\
\text { family care }\end{array}$ & $\mathrm{AU}$ & 2013 & 5 years & $\$ 9,2$ \\
\hline 7 & Newpin NSW SBB & $\begin{array}{l}\text { Children and } \\
\text { family care }\end{array}$ & $\mathrm{AU}$ & 2013 & 7 years & $\$ 6,4$ \\
\hline 8 & It's all about me Bond & $\begin{array}{l}\text { Children and } \\
\text { family care }\end{array}$ & UK & 2013 & 10 years & GBP 2 \\
\hline 9 & $\begin{array}{l}\text { Manchester City Council } \\
\text { Children in Care }\end{array}$ & $\begin{array}{l}\text { Children and } \\
\text { family care }\end{array}$ & UK & 2014 & 8 years & GBP 1,2 \\
\hline 10 & Essex County Council & $\begin{array}{l}\text { Children and } \\
\text { family care }\end{array}$ & UK & 2012 & 8 years & GBP 3,1 \\
\hline 11 & Saskatchewan & $\begin{array}{l}\text { Children and } \\
\text { family care }\end{array}$ & $\mathrm{CA}$ & 2014 & 5 years & $\$ 1$ \\
\hline 12 & $\begin{array}{l}\text { Utah School Readiness } \\
\text { Initiative }\end{array}$ & Education & U.S. & 2013 & 7 years & $\$ 7$ \\
\hline 13 & $\begin{array}{l}\text { Dropout rates from higher } \\
\text { education }\end{array}$ & Education & ISRAEL & $1 /$ & 4 years & $1 /$ \\
\hline 14 & Chicago Child Parent Center & Education & U.S. & 2014 & 4 years & $\$ 17$ \\
\hline 15 & $\begin{array}{l}\text { DWP Innovation Fund for } \\
\text { Young People } 10 \text { SIBs }\end{array}$ & Unemployment & UK & 2012 & 3 years & GBP 10 \\
\hline 16 & $\begin{array}{l}\text { New York State Social Impact } \\
\text { Partnership }\end{array}$ & Unemployment & U.S. & 2013 & 5,5 years & $\$ 13,5$ \\
\hline 17 & $\begin{array}{l}\text { Employment for young } \\
\text { migrants Duo for a Job }\end{array}$ & Unemployment & BELGIUM & 2014 & 3 years & $€ 0,234$ \\
\hline 18 & Buzinezzclub & Unemployment & NETHERLANDS & 2014 & 2 years & $€ 0,680$ \\
\hline 19 & Juvat & Unemployment & $\mathrm{DE}$ & 2013 & 2 years & /1 \\
\hline 20 & Bristol together & Unemployment & UK & 2012 & 5 years & GBP 1 \\
\hline 21 & Type 2 Diabetes & Health & ISRAEL & II & 1 year & 11 \\
\hline 22 & Fresno Asthma & Health & U.S. & 2013 & $\begin{array}{l}2 \text { year } \\
\text { (demonstration } \\
\text { project) }\end{array}$ & $\$ 1,1$ \\
\hline
\end{tabular}

${ }^{\mathrm{a}}$ Millions 
Table 2

Analysis of the first tear characteristics of a SIB

\begin{tabular}{|c|c|c|c|c|c|}
\hline \multirow[b]{2}{*}{$\#$} & \multicolumn{5}{|c|}{ First tear characteristics } \\
\hline & $\begin{array}{c}\text { New preventive and } \\
\text { innovative } \\
\text { intervention }\end{array}$ & $\begin{array}{c}\begin{array}{c}\text { Outcome } \\
\text { based } \\
\text { contract }\end{array} \\
\end{array}$ & $\begin{array}{l}\text { Presence of a commissioner and a } \\
\text { "delivery agency"/intermediary }\end{array}$ & $\begin{array}{c}\begin{array}{c}\text { Investors other than the } \\
\text { delivery agency and } \\
\text { commissioner }\end{array} \\
\end{array}$ & $\begin{array}{c}\text { Transfer of } \\
\text { risk to } \\
\text { investors }\end{array}$ \\
\hline 1 & $\checkmark$ & $\checkmark$ & $\checkmark$ & $\checkmark$ & $\checkmark$ \\
\hline 2 & $\checkmark$ & $\checkmark$ & $\checkmark$ & $\checkmark$ & $x$ \\
\hline 3 & $x$ & $\checkmark$ & $\checkmark$ & $\checkmark$ & $x$ \\
\hline 4 & $\checkmark$ & $\checkmark$ & $x$ & $\checkmark$ & $x$ \\
\hline 5 & $x$ & $\checkmark$ & $\checkmark$ & $\checkmark$ & $x$ \\
\hline 6 & $\checkmark$ & $r$ & $x$ & $\checkmark$ & $x$ \\
\hline 7 & $x$ & $\checkmark$ & $x$ & $\checkmark$ & $x$ \\
\hline 8 & $\checkmark$ & $\checkmark$ & 2 & $\checkmark$ & $\checkmark$ \\
\hline 9 & $x$ & $\checkmark$ & 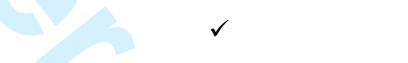 & $\checkmark$ & $\checkmark$ \\
\hline 10 & $x$ & $\checkmark$ & $\checkmark$ & $\checkmark$ & $\checkmark$ \\
\hline 11 & $x$ & $\checkmark$ & $x$ & $\checkmark$ & $\checkmark$ \\
\hline 12 & $x$ & $\checkmark$ & $\checkmark$ & $\checkmark$ & $x$ \\
\hline 13 & $x$ & $\checkmark$ & $\checkmark->=0$ & $\checkmark$ & $x$ \\
\hline 14 & $x$ & $\checkmark$ & $\checkmark$ & $\checkmark$ & $\checkmark$ \\
\hline 15 & $\checkmark$ & $\checkmark$ & Q & $\checkmark$ & $\checkmark$ \\
\hline 16 & $x$ & $\checkmark$ & $\checkmark$ & 12 & $x$ \\
\hline 17 & $x$ & $\checkmark$ & $\checkmark$ & $\checkmark$ & $\checkmark$ \\
\hline 18 & $\checkmark$ & $\checkmark$ & $\checkmark$ & $\checkmark$ & $x$ \\
\hline 19 & $\checkmark$ & $\checkmark$ & $\checkmark$ & $\checkmark$ & $\checkmark$ \\
\hline 20 & $x$ & $x$ & $\checkmark$ & $\checkmark$ & $x$ \\
\hline 21 & $\checkmark$ & $\checkmark$ & $\checkmark$ & $\checkmark$ & $\mathrm{NA}$ \\
\hline 22 & $\checkmark$ & $\checkmark$ & $\checkmark$ & $\checkmark$ & NA \\
\hline
\end{tabular}

${ }^{a}$ The risk is lowered by other private actors through guaranteeing part of the capital or the service provider contributes to the provision of the up-front capital. 
Table 3

Compliance-based analysis of SIB experiences

\begin{tabular}{|c|c|c|c|}
\hline GROUP & SIB & COUNTRY & SOCIAL ISSUE \\
\hline \multirow[t]{4}{*}{ FULL COMPLIANCE } & HM Peterborough & UK & CRIMINAL JUSTICE \\
\hline & It's all about me & UK & FAMILY AND CHILDREN \\
\hline & $\begin{array}{l}\text { DWP Innovation Fund for Young People } 10 \\
\text { SIBs }\end{array}$ & UK & UNEMPLOYEMENT \\
\hline & Drop out rates from higher education & IS & HIGHER EDUCATION \\
\hline \multirow[t]{10}{*}{ PARTIAL COMPLIANCE } & Saskatchewan & CANADA & $\overline{\text { FAMILY AND CHILDREN }}$ \\
\hline & Rikers Island & US & CRIMINAL JUSTICE \\
\hline & Street Impact & UK & ROUGH SLEEPING \\
\hline & Manchester City Council Children in Care & UK & FAMILY AND CHILDREN \\
\hline & Essex County Council & UK & FAMILY AND CHILDREN \\
\hline & New York State Social Impact Partnership & US & UNEMPLOYEMENT \\
\hline & $\begin{array}{l}\text { Employment for young migrants } \\
\text { Duo for a Job }\end{array}$ & BELGIUM & UNEMPLOYEMENT \\
\hline & Juvat & GERMANY & UNEMPLOYEMENT \\
\hline & Type 2 Diabetes & IS & HEALTH \\
\hline & Fresno Asthma & US & HEALTH \\
\hline \multirow{6}{*}{$\begin{array}{l}\text { MARGINAL } \\
\text { COMPLIANCE }\end{array}$} & Juvenile Justice Pay for Success Initiative & US & CRIMINAL JUSTICE \\
\hline & $\begin{array}{l}\text { Chronic Homeless - Social Innovation } \\
\text { Financing }\end{array}$ & US & ROUGH SLEEPING \\
\hline & Resilient Families Service SBB & $\mathrm{AU}$ & FAMILY AND CHILDREN \\
\hline & Utah School Readiness Initiative & US & $\begin{array}{l}\text { PRE SCHOOL } \\
\text { EDUCATION }\end{array}$ \\
\hline & Chicago Child-Parent Center & US & $\begin{array}{l}\text { PRE SCHOOL } \\
\text { EDUCATION }\end{array}$ \\
\hline & Buzinezzclub & NETHERLANDS & UNEMPLOYEMENT \\
\hline
\end{tabular}

URL: http:/mc.manuscriptcentral.com/Ipad Email: michael.macaulay@vuw.ac.nz, afarazma@fau.edu 
Annex 1

Second Tear Characteristics Of The Configuration Of A Social Impact Bond

\begin{tabular}{|c|c|c|c|c|c|c|c|c|c|c|c|}
\hline \multirow[b]{2}{*}{$\#$} & \multicolumn{3}{|c|}{ GENERAL INFORMATION } & \multicolumn{3}{|c|}{ SOCIAL ISSUE AND INTERVENTION } & \multicolumn{2}{|c|}{ SIB GOVERNANCE } & \multicolumn{3}{|c|}{ SIB STRUCTURE } \\
\hline & SIB & COUNTRY & SOCIAL ISSUE & $\begin{array}{c}\text { COVERAGE } \\
\text { OF THE } \\
\text { SOCIAL } \\
\text { ISSUE }\end{array}$ & $\begin{array}{l}\text { INNOVATION } \\
\text { OF THE } \\
\text { PROGRAM }\end{array}$ & $\begin{array}{c}\text { TARGET } \\
\text { AREA }\end{array}$ & $\begin{array}{l}\text { NATURE OF } \\
\text { PROMOTER }\end{array}$ & $\begin{array}{c}\text { INVOLVEMENT } \\
\text { OF } \\
\text { COMMISSIONER }\end{array}$ & $\begin{array}{l}\text { FLEXIBILITY } \\
\text { OF DELIVERY } \\
\text { STRUCTURE }\end{array}$ & $\begin{array}{c}\text { RISK } \\
\text { ALLOCATION }\end{array}$ & $\begin{array}{c}\text { DISTRIBUTION } \\
\text { OF } \\
\text { POTENTIAL } \\
\text { SAVINGS }\end{array}$ \\
\hline 1 & $\begin{array}{c}\text { HM } \\
\text { Peterborough }\end{array}$ & $\overline{U K}$ & CRIMINAL JUSTICE & $\begin{array}{l}\text { Uncovered since } \\
\text { it is not a } \\
\text { statutory service }\end{array}$ & New program & Local & $\begin{array}{c}\text { Public - } \\
\text { National Level }\end{array}$ & $\begin{array}{l}\text { Low level of } \\
\text { involvement }\end{array}$ & $\begin{array}{l}\text { Flexible and } \\
\text { collaborative }\end{array}$ & $\begin{array}{l}\text { All risk on } \\
\text { investors }\end{array}$ & Intermediate \\
\hline 2 & Rikers Island & US & CRIMINAL JUSTICE & $\begin{array}{l}\text { Area left } \\
\text { uncovered by } \\
\text { the public sector } \\
\text { offerings }\end{array}$ & New program & Local & $\begin{array}{c}\text { Public - Local } \\
\text { Level }\end{array}$ & $\begin{array}{l}\text { High level of } \\
\text { involvement }\end{array}$ & $\begin{array}{l}\text { Flexible and } \\
\text { collaborative }\end{array}$ & $\begin{array}{l}\text { Presence of capital } \\
\text { protection } \\
\text { measures }\end{array}$ & Intermediate \\
\hline 3 & $\begin{array}{l}\text { Juvenile } \\
\text { Justice Pay } \\
\text { for Success } \\
\text { Initiative }\end{array}$ & US & CRIMINAL JUSTICE & $\begin{array}{l}\text { Area left } \\
\text { uncovered by } \\
\text { the public sector } \\
\text { offerings }\end{array}$ & $\begin{array}{l}\text { Expansion of the } \\
\text { existing program } \\
\text { of a service } \\
\text { provider }\end{array}$ & Local & $\begin{array}{c}\text { Public - State } \\
\text { Level }\end{array}$ & $\begin{array}{l}\text { High level of } \\
\text { involvement }\end{array}$ & $\begin{array}{l}\text { Stand-alone } \\
\text { program }\end{array}$ & $\begin{array}{c}\text { Presence of capital } \\
\text { protection } \\
\text { measures and risk } \\
\text { sharing } \\
\text { arrangements } \\
\end{array}$ & Intermediate \\
\hline 4 & Street Impact & UK & ROUGH SLEEPING & $\begin{array}{l}\text { Covered by the } \\
\text { public offerings, } \\
\text { but with very } \\
\text { poor outcomes }\end{array}$ & New program & Local & $\begin{array}{l}\text { Public-Local } \\
\text { and National } \\
\text { Level }\end{array}$ & $\begin{array}{l}\text { High level of } \\
\text { involvement }\end{array}$ & $\begin{array}{l}\text { Flexible and } \\
\text { collaborative }\end{array}$ & $\begin{array}{l}\text { Presence of risk } \\
\text { sharing } \\
\text { arrangements }\end{array}$ & Indirect \\
\hline 5 & $\begin{array}{c}\text { Chronic } \\
\text { Homeless - } \\
\text { Social } \\
\text { Innovation } \\
\text { Financing }\end{array}$ & US & ROUGH SLEEPING & $\begin{array}{l}\text { Uncovered by } \\
\text { the public } \\
\text { offerings }\end{array}$ & $\begin{array}{l}\text { Expansion of the } \\
\text { existing program } \\
\text { of a service } \\
\text { provider }\end{array}$ & Regional & $\begin{array}{c}\text { Public-State } \\
\text { Level }\end{array}$ & $\begin{array}{l}\text { High level of } \\
\text { involvement }\end{array}$ & $\begin{array}{l}\text { Stand-alone } \\
\text { program }\end{array}$ & $\begin{array}{l}\text { Presence of capital } \\
\text { protection } \\
\text { measures }\end{array}$ & Indirect \\
\hline 6 & $\begin{array}{c}\text { Resilient } \\
\text { Families } \\
\text { Service SBB }\end{array}$ & $\overline{\mathrm{AU}}$ & $\begin{array}{l}\text { FAMILY AND } \\
\text { CHILDREN }\end{array}$ & $\begin{array}{l}\text { Covered by the } \\
\text { public offerings, } \\
\text { but with very } \\
\text { poor outcomes }\end{array}$ & New program & Regional & Private entities & $\begin{array}{l}\text { High level of } \\
\text { involvement }\end{array}$ & $\begin{array}{l}\text { Stand-alone } \\
\text { program }\end{array}$ & $\begin{array}{l}\text { Presence of capital } \\
\text { protection } \\
\text { measures }\end{array}$ & $\overline{\text { Direct }}$ \\
\hline 8 & $\begin{array}{c}\text { It's all about } \\
\text { me }\end{array}$ & UK & $\begin{array}{l}\text { FAMILY AND } \\
\text { CHILDREN }\end{array}$ & $\begin{array}{l}\text { Covered by the } \\
\text { public offerings, } \\
\text { but with very } \\
\text { poor outcomes }\end{array}$ & New program & Nationwide & $\begin{array}{l}\text { Private entities } \\
\text { (Not for profit) }\end{array}$ & $\begin{array}{l}\text { Low level of } \\
\text { involvement }\end{array}$ & $\begin{array}{l}\text { Flexible and } \\
\text { collaborative }\end{array}$ & $\begin{array}{l}\text { All risk on } \\
\text { investors }\end{array}$ & Direct \\
\hline 9 & $\begin{array}{c}\text { Manchester } \\
\text { City Council } \\
\text { Children in } \\
\text { Care } \\
\end{array}$ & UK & $\begin{array}{l}\text { FAMILY AND } \\
\text { CHILDREN }\end{array}$ & $\begin{array}{l}\text { Uncovered by } \\
\text { the public } \\
\text { offerings }\end{array}$ & $\begin{array}{l}\text { Implementation of } \\
\text { a program already } \\
\text { proven successful }\end{array}$ & Regional & $\begin{array}{c}\text { Public - Local } \\
\text { Level }\end{array}$ & $\begin{array}{l}\text { High level of } \\
\text { involvement }\end{array}$ & $\begin{array}{l}\text { Stand-alone } \\
\text { program }\end{array}$ & $\begin{array}{l}\text { All risk on } \\
\text { investors }\end{array}$ & Direct \\
\hline
\end{tabular}

URL: http:/mc.manuscriptcentral.com/Ipad Email: michael.macaulay@vuw.ac.nz, afarazma@fau.edu 


\begin{tabular}{|c|c|c|c|c|c|c|c|c|c|c|c|}
\hline 10 & $\begin{array}{c}\text { Essex County } \\
\text { Council }\end{array}$ & UK & $\begin{array}{l}\text { FAMILY AND } \\
\text { CHILDREN }\end{array}$ & $\begin{array}{l}\text { Uncovered by } \\
\text { the public } \\
\text { offerings }\end{array}$ & $\begin{array}{l}\text { Implementation of } \\
\text { a program already } \\
\text { proven successful }\end{array}$ & Regional & $\begin{array}{l}\text { Public-Local } \\
\text { Level }\end{array}$ & $\begin{array}{c}\text { High level of } \\
\text { involvement }\end{array}$ & $\begin{array}{l}\text { Flexible and } \\
\text { collaborative }\end{array}$ & $\begin{array}{c}\text { All risk on } \\
\text { investors }\end{array}$ & Direct \\
\hline 11 & Saskatchewan & CANADA & $\begin{array}{l}\text { FAMILY AND } \\
\text { CHILDREN }\end{array}$ & $\begin{array}{l}\text { Covered by the } \\
\text { public offerings, } \\
\text { but with very } \\
\text { poor outcomes }\end{array}$ & $\begin{array}{l}\text { Expansion of an } \\
\text { existing program }\end{array}$ & Local & $\begin{array}{l}\text { Public-State } \\
\text { Level }\end{array}$ & $\begin{array}{c}\text { High level of } \\
\text { involvement }\end{array}$ & $\begin{array}{c}\text { Stand-alone } \\
\text { program }\end{array}$ & $\begin{array}{c}\text { All risk on } \\
\text { investors }\end{array}$ & Direct \\
\hline 12 & $\begin{array}{c}\text { Utah School } \\
\text { Readiness } \\
\text { Initiative }\end{array}$ & US & $\begin{array}{l}\text { PRE SCHOOL } \\
\text { EDUCATION }\end{array}$ & $\begin{array}{l}\text { Covered by the } \\
\text { public offerings, } \\
\text { but with very } \\
\text { poor outreach }\end{array}$ & $\begin{array}{l}\text { Expansion of an } \\
\text { existing program }\end{array}$ & Local & $\begin{array}{l}\text { Public-State } \\
\text { Level }\end{array}$ & $\begin{array}{l}\text { Low level of } \\
\text { involvement }\end{array}$ & $\begin{array}{c}\text { Stand-alone } \\
\text { program }\end{array}$ & $\begin{array}{l}\text { Presence of capital } \\
\text { protection } \\
\text { measures }\end{array}$ & Indirect \\
\hline 13 & $\begin{array}{c}\text { Chicago } \\
\text { Child-Parent } \\
\text { Center }\end{array}$ & US & $\begin{array}{l}\text { PRE SCHOOL } \\
\text { EDUCATION }\end{array}$ & $\begin{array}{l}\text { Covered by the } \\
\text { public offerings, } \\
\text { but with very } \\
\text { poor outreach }\end{array}$ & $\begin{array}{c}\text { Expansion of } \\
\text { existing program }\end{array}$ & Local & $\begin{array}{l}\text { Public- Local } \\
\text { Level }\end{array}$ & $\begin{array}{l}\text { High level of } \\
\text { involvement }\end{array}$ & $\begin{array}{c}\text { Stand-alone } \\
\text { program }\end{array}$ & $\begin{array}{l}\text { Presence of capital } \\
\text { protection } \\
\text { measures }\end{array}$ & Indirect \\
\hline 14 & $\begin{array}{c}\text { Drop out } \\
\text { rates from } \\
\text { higher } \\
\text { education }\end{array}$ & IS & $\begin{array}{c}\text { HIGHER } \\
\text { EDUCATION }\end{array}$ & $\begin{array}{l}\text { Uncovered since } \\
\text { it is not a } \\
\text { statutory service }\end{array}$ & New program & UNKNOWN & Private entities & $\begin{array}{l}\text { Low level of } \\
\text { involvement }\end{array}$ & $\begin{array}{l}\text { Flexible and } \\
\text { collaborative }\end{array}$ & $\begin{array}{c}\text { All risk on } \\
\text { investors }\end{array}$ & Indirect \\
\hline 15 & $\begin{array}{c}\text { DWP } \\
\text { Innovation } \\
\text { Fund for } \\
\text { Young People } \\
10 \text { SIBs } \\
\end{array}$ & $\overline{\mathrm{UK}}$ & UNEMPLOYEMENT & $\begin{array}{l}\text { Covered by the } \\
\text { public offerings, } \\
\text { but with very } \\
\text { poor outcomes }\end{array}$ & New program & Nationwide & $\begin{array}{c}\text { Public- } \\
\text { National Level }\end{array}$ & $\begin{array}{c}\text { High level of } \\
\text { involvement }\end{array}$ & $\begin{array}{l}\text { Flexible and } \\
\text { collaborative }\end{array}$ & $\begin{array}{c}\text { All risk on } \\
\text { investors }\end{array}$ & Intermediate \\
\hline 16 & $\begin{array}{c}\text { New York } \\
\text { State Social } \\
\text { Impact } \\
\text { Partnership }\end{array}$ & US & UNEMPLOYEMENT & $\begin{array}{l}\text { Uncovered by } \\
\text { the public } \\
\text { offerings }\end{array}$ & $\begin{array}{l}\text { Expansion of an } \\
\text { existing program }\end{array}$ & Local & $\begin{array}{c}\text { Public-State } \\
\text { Level }\end{array}$ & $\begin{array}{l}\text { Low level of } \\
\text { involvement }\end{array}$ & $\begin{array}{c}\text { Stand-alone } \\
\text { program }\end{array}$ & $\begin{array}{l}\text { Presence of capital } \\
\text { protection } \\
\text { measures }\end{array}$ & Intermediate \\
\hline 17 & $\begin{array}{c}\text { Employment } \\
\text { for young } \\
\text { migrants } \\
\text { Duo for a Job }\end{array}$ & BELGIUM & UNEMPLOYEMENT & $\begin{array}{l}\text { Uncovered by } \\
\text { the public } \\
\text { offerings }\end{array}$ & $\begin{array}{l}\text { Expansion of an } \\
\text { existing program }\end{array}$ & Local & $\begin{array}{l}\text { Public-Local } \\
\text { Level }\end{array}$ & $\begin{array}{l}\text { Low level of } \\
\text { involvement }\end{array}$ & $\begin{array}{c}\text { Stand-alone } \\
\text { program }\end{array}$ & $\begin{array}{c}\text { All risk on } \\
\text { investors }\end{array}$ & Intermediate \\
\hline 18 & Buzinezzclub & NETHERLANDS & UNEMPLOYEMENT & $\begin{array}{l}\text { Uncovered by } \\
\text { the public } \\
\text { offerings }\end{array}$ & New program & Local & $\begin{array}{l}\text { Public- Local } \\
\text { Level }\end{array}$ & $\begin{array}{c}\text { High level of } \\
\text { involvement }\end{array}$ & $\begin{array}{l}\text { Stand-alone } \\
\text { program }\end{array}$ & $\begin{array}{l}\text { Presence of risk } \\
\text { sharing } \\
\text { arrangements }\end{array}$ & Indirect \\
\hline 19 & Juvat & GERMANY & UNEMPLOYEMENT & $\begin{array}{l}\text { Uncovered by } \\
\text { the public } \\
\text { offerings }\end{array}$ & New program & Local & $\begin{array}{l}\text { Public-Local } \\
\text { Level }\end{array}$ & NA & $\begin{array}{l}\text { Flexible and } \\
\text { collaborative }\end{array}$ & $\begin{array}{c}\text { All risk on } \\
\text { investors }\end{array}$ & Intermediate \\
\hline 21 & $\begin{array}{c}\text { Type 2 } \\
\text { Diabetes }\end{array}$ & $\overline{I S}$ & $\overline{\text { HEALTH }}$ & $\begin{array}{l}\text { Uncovered since } \\
\text { it is not a } \\
\text { statutory service }\end{array}$ & New program & $\mathrm{ND}$ & Private entity & $\overline{\mathrm{NA}}$ & $\begin{array}{c}\text { Stand-alone } \\
\text { program }\end{array}$ & $\overline{\mathrm{NA}}$ & Direct \\
\hline 22 & $\begin{array}{c}\text { Fresno } \\
\text { Asthma }\end{array}$ & US & HEALTH & $\begin{array}{l}\text { Uncovered since } \\
\text { it is not a } \\
\text { statutory service }\end{array}$ & New program & Local & Private entity & $\mathrm{NA}$ & $\begin{array}{l}\text { Stand-alone } \\
\text { program }\end{array}$ & $\mathrm{NA}$ & Direct \\
\hline
\end{tabular}

